\title{
Crested Wheatgrass Response to Nitrogen and Clipping
}

\author{
FORREST A. SNEVA
}

Highlight: Nitrogen fertilizer at $30 \mathrm{lb}$./acre increased 13-year mean spring, regrowth, and fall yields of crested wheatgrass 83,29 , and $78 \%$, respectively, above control plot yield. It increased the crude protein concentration of mature herbage, but the protein concentration decreased as fall yields increased. Mean spring plus regrowth yield, with and without $N$, was 82 and $85 \%$, respectively, of the fall yield harvest on August 1 . Forty-six and fifty-two percent of the fall yield with and without $N$, respectively, was present on May 15. Yield measurements in the 7 th and 13th year revealed no yield reduction due to previous treatment on control plots but did show significant reductions in yield on plots fertilized with $N$ and clipped in previous years on May 15. Those yield reductions were interpreted to be the result of restricted regrowth opportunity in the previous year due to weather and not to cumulative yearly clipping effects.

Fertilizer trials on native or introduced grass species within the intermountain area, for the most part, have been evaluated at the hay stage or at maturity. Clipping influence studies, though more numerous, have been of short duration and the conclusions reached are therefore restricted. The need for long term results to evaluate year influence upon fertilizer and clipping effects prompted the establishment of this study in 1957.

This paper presents 13 years of spring,

\section{Materials and Methods}

The Squaw Butte Experiment Station is situated in southeastern Oregon within the northern fringe of the Great Basin. Thirty-year mean crop-year (September 1 through June 30,) precipitation is 10.9 inches. The highly variable and unclassified soils support a variety of vegetation types; the most common is big sagebrushbluebunch wheatgrass (Artemisia tridentata - Agropyron spicatum). The soils are sandy loams of basaltic origin and are underlaid with a caliche layer varying (regrowth yield). Spring yield plus regrowth is referred to herein as total yield.

Herbage samples were dried in a forced-air oven $(165 \mathrm{~F})$ and yield is reported as air dry (10\% moisture). Herbage clipped to estimate fall yield was composited by treatments, ground through a Wiley mill, subsampled, and retained for Kjeldahl-N determinations; $\mathrm{N}$ concentrations are reported as crude protein $(\mathrm{N} \times 6.25)$.

The data were analyzed as a randomized complete block using years as subplots. Three separate analyses on combined year data were conducted, i.e., spring versus fall yield, total versus fall yield, and regrowth yield. Differences between means were tested with Duncan's multiple range test.

In 1963 and 1969, yield samples from a randomly chosen half of each plot were taken on May 15; the remaining half of each plot was sampled on August 1 . Regrowth from those halves harvested on May 15 was also sampled on August 1. These uniform date samples were analyzed as a $2 \times 2$ factorial in randomized block design for determining previous years' treatment influence. Herbage samples were handled as described above. Kjeldahl-N was determined for each fall yield sample in both years and for spring and regrowth samples in 1969 only.

Table 1. Herbage yield (lb./acre) and yield increase (\%) due to $\mathrm{N}$ (lb./acre).

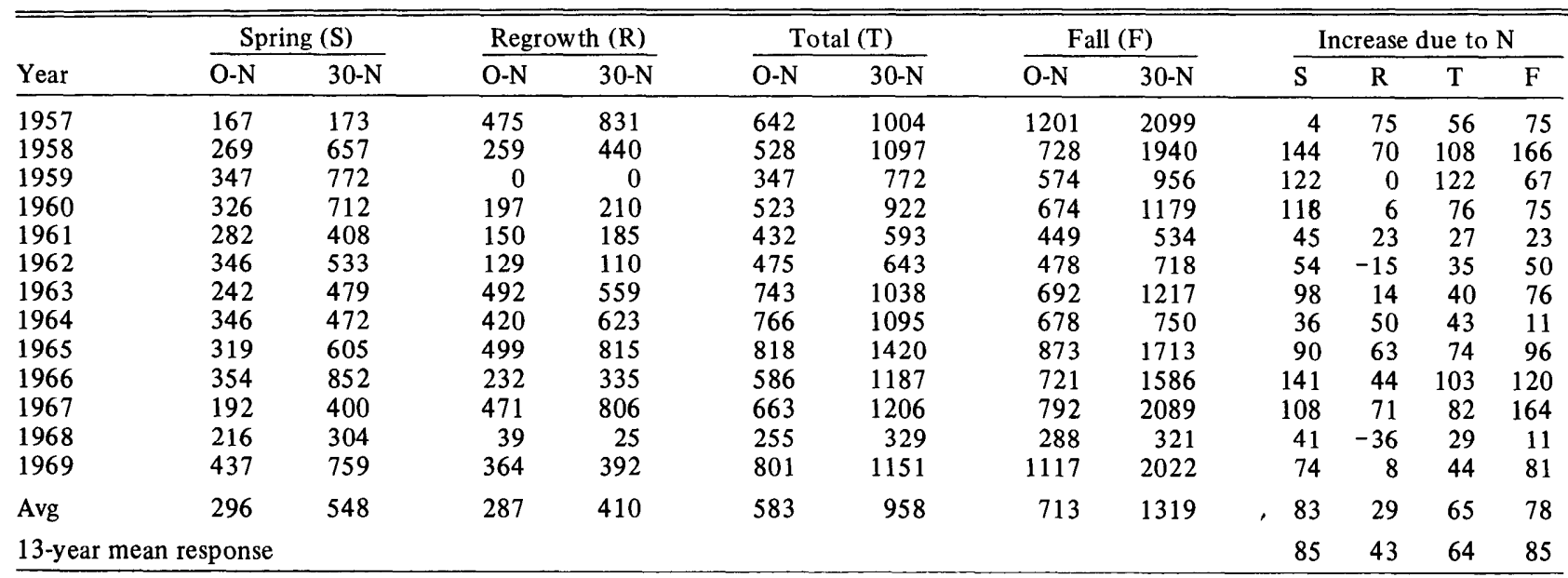

spring + regrowth, and fall yields of crested wheatgrass (Agropyron desertorum [Fisch.] Schult.) grown on permanent plots with and without nitrogen (N) fertilizer.

The author is range scientist at the Plant Science Research Division, Agricultural Research Division, U. S. Department of Agriculture, Burns, Ore.

The paper is a contribution from the Squaw Butte Experiment Station, Burns, Ore. financed cooperatively by the Plant Science Research Division, Agr. Res. Serv., U. S. Dep. Agr., and the Oregon Agricultural Experiment Staand the Oregon Agricultural Experiment StaState University Technical Paper No. 2883.) Manuscript received September 30, 1971. from 2 to 4 feet below the surface. Eckert (1957) has described these soils in greater detail.

Two fertilizer levels ( 0 and $30 \mathrm{lb}$./acre) and two harvest dates (spring and fall) in factorial combination within each of five replications comprised the randomized block experiment. Ammonium nitrate at $30 \mathrm{lb}$. of elemental $\mathrm{N}(30-\mathrm{N})$ was first applied to the plots in February, 1957, and annually thereafter in the fall. Herbage from $48 \mathrm{ft}^{2}$ within each $10 \times 12-\mathrm{ft}$ treatment plot was harvested to ground level on May 15 (spring yield) and on August 1 (fall yield). Regrowth on spring harvested plots was sampled on August 1

\section{Results}

Annual yield for each harvest in each year and the yield increase due to $\mathrm{N}$ is presented in Table 1. Seasonal yield portions, crude protein concentrations and $\mathrm{N}$-yield of fall harvested herbage, and crop-year precipitation is shown in Table 2. As determined by analysis of variance, $\mathrm{N}$, harvest date, year, and their interactions for all analyses, except $\mathrm{N}$ by harvest-date for total versus fall yield analysis, were highly significant $(\mathrm{P}<$ 0.01).

Summations of the response to $\mathrm{N}$ and 
Table 2. Seasonal yield portions (\%), crude protein concentrations (\%), and $\mathrm{N}$ yield (lb./acre) of fall harvested herbage, and crop-year precipitation (inches) for the years 1957 to 1969.

\begin{tabular}{|c|c|c|c|c|c|c|c|c|c|c|c|}
\hline \multirow[b]{2}{*}{ Year } & \multicolumn{2}{|c|}{ Spring/fall } & \multicolumn{2}{|c|}{ Total/fall } & \multicolumn{2}{|c|}{ Regrowth/fall } & \multicolumn{2}{|c|}{ Crude protein 1} & \multicolumn{2}{|c|}{ N-yield ${ }^{1}$} & \multirow{2}{*}{$\begin{array}{c}\text { Crop-year } \\
\text { precipitation }\end{array}$} \\
\hline & $\mathrm{O}-\mathrm{N}$ & $30-N$ & $\mathrm{O}-\mathrm{N}$ & $30-\mathrm{N}$ & $\mathrm{O}-\mathrm{N}$ & $30-\mathrm{N}$ & $\mathrm{O}-\mathrm{N}$ & $30-\mathrm{N}$ & $\mathrm{O}-\mathrm{N}$ & $30-\mathrm{N}$ & \\
\hline 1957 & 14 & 8 & 53 & 48 & 40 & 40 & 2.7 & 3.6 & 5.2 & 12.1 & 13.0 \\
\hline 1958 & 37 & 34 & 73 & 57 & 36 & 23 & 3.9 & 3.3 & 4.5 & 10.2 & 15.8 \\
\hline 1959 & 60 & 81 & 60 & 81 & 0 & 0 & 3.9 & 5.2 & 3.6 & 8.0 & 5.8 \\
\hline 1960 & 48 & 60 & 78 & 78 & 29 & 18 & 4.4 & 6.2 & 4.7 & 11.7 & 9.2 \\
\hline 1961 & 63 & 74 & 96 & 107 & 33 & 33 & 6.1 & 9.4 & 4.3 & 8.3 & 7.0 \\
\hline 1962 & 72 & 74 & 99 & 90 & 27 & 15 & 6.0 & 9.7 & 4.6 & 11.1 & 7.5 \\
\hline 1963 & 35 & 39 & 107 & 85 & 71 & 46 & 5.8 & 9.5 & 6.4 & 18.5 & 13.5 \\
\hline 1964 & 51 & 63 & 113 & 146 & 62 & 83 & 4.6 & 8.6 & 5.0 & 10.3 & 10.5 \\
\hline 1965 & 37 & 35 & 94 & 83 & 57 & 48 & 5.0 & 6.4 & 7.0 & 17.5 & 12.5 \\
\hline 1966 & 49 & 54 & 81 & 75 & 32 & 21 & 3.9 & 6.2 & 4.5 & 15.7 & 7.7 \\
\hline 1967 & 24 & 19 & 84 & 58 & 59 & 39 & 4.1 & 5.9 & 5.2 & 19.7 & 11.4 \\
\hline 1968 & 75 & 95 & 89 & 102 & 13 & 8 & 4.9 & 10.9 & 2.3 & 5.6 & 4.9 \\
\hline 1969 & 39 & 38 & 72 & 57 & 33 & 19 & 4.3 & 7.7 & 7.7 & 24.9 & 10.7 \\
\hline Avg & 46 & 52 & 85 & 82 & 38 & 30 & 4.6 & 7.1 & 5.0 & 13.4 & 10.0 \\
\hline $\operatorname{Mean}^{3}$ & 47 & 42 & 82 & 72 & 40 & 31 & - & - & - & - & - \\
\hline
\end{tabular}

Fall harvest

${ }_{3}^{2}$ September 1 previous year to June 30 , inc.

3 13-year mean response

seasonal yield portions in Tables 1 and 2 are presented as (1) averages of annual effects and (2) means based upon the 13-year mean yield. The interpretation of the data will be, for simplicity, based upon averages of annual effects. This should not be construed that summations based upon the 13-year means are less correct.

\section{Herbage Yields}

Mean spring yield of unfertilized plots ranged from 167 to $437 \mathrm{lb}$./acre and averaged $296 \mathrm{lb}$./acre. Mean spring yicld of control plots averaged $46 \%$ of the mean fall yield. With $30-\mathrm{N}$, spring yield was increased $83 \%$, the yield range was increased, and the amount present on May 15 averaged $52 \%$ of the fall yield. Yield increase, due to $\mathrm{N}$, varied through the years from 4 to $144 \%$.

The unfertilized regrowth yield averaged slightly less than that of spring yield ( 287 vs $296 \mathrm{lb}$./acre, respectively) but with $\mathrm{N}$ the regrowth yield was increased approximately $29 \%$ above the control. Nitrogen depressed regrowth yield below that of control plots in two years. In 1959 no measurable regrowth occurred on any plot.

Mean fall yield was increased 78\% above the control with $30-\mathrm{N}$, but the increase varied among years from 11 to $166 \%$. The larger yield increases occurred in those years receiving above normal precipitation.

The mean total yield of control plots was approximately $15 \%$ less than those harvested on August 1. Nitrogen altered the comparison very little (3\%). Total yield was greater than fall yield in two years without $\mathrm{N}$ and in three years with N. Only in 1964 was this yield difference of any great magnitude.

\section{Crude Protein Concentration and Nitrogen Yield}

Mature herbage from unfertilized plots contained an average of $4.6 \%$ crude protein. This varied through the years from 2.7 to $6.1 \%$ and was significantly $(\mathrm{P}<$ $0.05)$ correlated with herbage yield $(r=$ -0.64) but not with crop-year precipitation $(r=0.27)$. Nitrogen increased the average crude protein concentration to $7.1 \%$ and only in one year was percent crude protein not increased. A higher correlation was found with percent crude protein and herbage yield on fertilized plots $(r=-0.78)$.

The mean annual yield of $\mathrm{N}$ in plants on August 1 was 5.0 and $13.4 \mathrm{lb}$./acre from unfertilized and fertilized plots, respectively. Thus, the mean recovery of applied $\mathrm{N}$ was approximately $29 \%$. Recovery varied from $11 \%$ in the drought year of 1968 to $57 \%$ in the following year, which received near normal precipitation. Nitrogen yield from nonfertilized plots was significantly $(\mathrm{P}<0.05)$ correlated with crop-year precipitation $(\mathrm{r}=$ $0.61)$ but that from fertilized plots was not $(r=0.46)$.

\section{Clipping Influence}

On nonfertilized plots, cumulative effects of harvesting in the spring, plus its regrowth on August 1, versus harvesting in the fall only were not significantly different when measured by spring, regrowth, or fall yield (Table 3 ). On fertilized plots, harvesting on May 15 and its regrowth on August 1 in the 6 or 12 years previous significantly reduced spring yield in 1963 and 1969, 36 and 16\%, respectively, compared with that produced from plots harvested previously on August 1 only. Previous years clipping treatment did not affect regrowth yield in either 1963 or 1969 . Mean yields in the fall of 1963 and 1969 on fertilized plots clipped on May 15 in previous years were lower than yield from plots previously harvested on August 1; but these differences were not significant $(P>0.05)$.

Significantly higher $(\mathrm{P}<0.05)$ concentrations of crude protein were tound in herbage clipped on August 1, 1963, from plots harvested in the spring than from plots harvested in the fall in the previous 6 years (Table 4). No significant difference $(P>0.05)$ in crude protein concentration in 1969 spring, regrowth, or fall herbage was found due to clipping treatment in the previous 12 years.

\section{Discussion}

In the spring of 1957 grasses on fertilized plots were chlorotic. Chlorosis of lesser intensity in grasses on fertilized plots was also observed in some of the subsequent years. Positive grass response to and correction of the chlorosis with sulphur in 1971 suggest that sulphur may have limited grass response to $\mathrm{N}$ in some of the study years. Generally speaking, the mean results reflect a below normal precipitation regime. More than half the study years received less than normal crop-year precipitation, and in 1959 and 1968 extreme drought conditions existed.

Summations based upon annual averages approximated those based upon 13-year means for all comparisons except four. In those cases interpretation of the results would be changed; however, whether those would be significant changes is questionable. The truth probably lies somewhere between. It is pro- 
Table 3. Herbage yield (lb./acre) in 1963 and 1969 as influenced by nitrogen and clipping treatments in 6 and 12 previous years.

\begin{tabular}{|c|c|c|c|c|}
\hline \multirow[b]{3}{*}{ Time of harvest } & \multicolumn{4}{|c|}{ Previous year's harvesting and $N$ treatment 1} \\
\hline & \multicolumn{2}{|c|}{ May $15^{2}$} & \multicolumn{2}{|c|}{ Aug. 1} \\
\hline & $\mathrm{O}-\mathrm{N}$ & $30-\mathrm{N}$ & $\overline{\mathrm{O}-\mathrm{N}}$ & $30-\mathrm{N}$ \\
\hline May 15,1963 & $242^{\mathrm{a}}$ & $479^{b}$ & $247^{a}$ & $750^{c}$ \\
\hline Aug. 1,1963 (regrowth) & $492^{a}$ & $559^{\mathrm{a}}$ & $444^{\mathrm{a}}$ & $594^{\mathrm{a}}$ \\
\hline Aug. 1,1963 & $644^{\mathrm{a}}$ & $944^{b}$ & $692^{a}$ & $1217^{b}$ \\
\hline May 15,1969 & $437^{\mathrm{a}}$ & $759^{b}$ & $372^{\mathrm{a}}$ & $906^{\mathrm{c}}$ \\
\hline Aug. 1,1969 (regrowth) & $364^{\mathrm{a}}$ & $392^{\mathrm{a}}$ & $314^{\mathrm{a}}$ & $482^{\mathrm{a}}$ \\
\hline Aug. 1, 1969 & $1069^{a}$ & $1572^{b}$ & $1117^{\mathrm{a}}$ & $2022^{b}$ \\
\hline
\end{tabular}

${ }^{1}$ Means within a row with similar superscripts are not significantly different $(P<0.05)$.

2 This treatment also includes the effects of harvesting the regrowth of these grasses on August 1.

bab.y more important to recognize that even 13 years of data was not sufficient to average out results of extreme year fluc:uations in all comparisons.

The primary role of crested wheatgrass in range improvement has been to provide (1) an early grazable forage and (2) a grass tolerant of that early grazing. Hyder (1967), after an analysis of forage requirements for beef gain on blue grama range, suggested that 250 or $300 \mathrm{lb}$./acre of high quality forage be available for optimum animal gain. Sharp (1970), reporting grazing results on crested wheatgrass in Idaho, also indicated the need for production to be 200 to $300 \mathrm{lb}$./acre to provide adequate forage to meet animal requirements. Based upon those findings and the yields obtained in this study, crested wheatgrass should provide an adequate volume of forage for the grazing animal in most years by May 15 on range areas near this Station. Because of extreme year variation the operator should recognize that in about $25 \%$ of the years, unfertilized crested wheatgrass production in the forepart of May will be below that requirement level.

Thirty pounds of $\mathrm{N}$ increased spring yield to the extent that in all but one year, production exceeded $300 \mathrm{lb}$./acre on May 15. Thus, if production is the only concern, annual applications of $\mathrm{N}$ could alleviate low early spring production in some years and possibly allow for earlier grazing in other years.

Each pound of $\mathrm{N}$ applied returned approximately $8 \mathrm{lb}$. of additional spring herbage. When regrowth yields were included, this return increased to $12 \mathrm{lb}$. Twenty pounds of additional herbage per pound of $\mathrm{N}$ applied were realized when the grass was permitted to mature before harvesting. This latter return is similar to that obtained in earlier studies by Sneva et al. (1958) and Sneva (1965). Fall return was considerably greater than spring return; but it may not be as valuable since (1) the herbage is of low quality and (2) a forage shortage is not normally present in late summer. Nitrogen can provide more spring or late summer forage, but its cost and return need to be compared with other alternatives.

Emphasis on the efficiency of water use has recently become a measure of interest. In this study the efficiency of water use for fall production was $71 \mathrm{lb}$. and $131 \mathrm{lb}$. of herbage per inch of crop-year precipitation received on control and 30-N plots, respectively.

The similarity in response to $\mathrm{N}$ in spring and fall yields suggests that $\mathrm{N}$ apparently stimulates physiological activity prior to May 15 and that subsequent growth is proportional to the amount of leaf tissue present and active. This is supported by a similar growth ratio $(1.4: 1)$ for fertilized and unfertilized growth that was obtained when growth after May 15 (fall minus spring yield) was expressed as a ratio of spring yield.

Yield response to $\mathrm{N}$ was slightly greater on May 15 in wet years (over 11 inches) than in dry years (under 11 inches) and this difference increased by the time of the fall harvest. Fifty-seven percent of the fall yield was present on unfertilized plots on May 15 in dry years as compared to $30 \%$ in wet years. Nitrogen increased the proportion present on May 15 to $67 \%$ in dry years but did not influence this relation in wet years. Vari- ability as well as production is increased under $\mathrm{N}$ fertilization, therefore management needs are also intensified.

The increase in crude protein concentration of mature herbage with $30-\mathrm{N}$ is a fact, but its significance could be tempered by the conditions occurring during this study and by relevant knowledge. A previous study (Sneva et al., 1958) established $20-\mathrm{N}$ as the most efficient $\mathrm{N}$ level for increasing herbage yields. In that study, $\mathrm{N}$ levels of 30 -or 40-N increased crude protein concentrations in the second-year-growth herbage, when precipitation in the first year was below normal but not when the first year precipitation was above normal. It appears that because of the greater amount of subnormal precipitation occurring throughout this study, the increase in crude protein concentration due to $\mathrm{N}$ is biased, perhaps to a greater extent than is herbage yield. Furthermore, under more favorable moisture conditions, yield response would be slightly greater and crude protein concentration diminished with 30-N.

Recovery of applied $\mathrm{N}$ was low, and previously published information (Sneva et al., 1958) suggest that only a small increase in recovery could be gained through residual effects. Harvesting at a date earlier than August 1 could improve $\mathrm{N}$ recovery considerably. Sneva et al. (1958) reported $\mathrm{N}$ yield losses of 50\% in fertilized crested wheatgrass from June 1 to August 1. Thus, the mean $\mathrm{N}$ yield of 5.0 and $13.3 \mathrm{lb}$./acre for unfertilized and fertilized grasses, respectively, do not estimate the maximum amount of $\mathrm{N}$ that could be removed through grazing.

Hyder and Sneva (1961) concluded that $\mathrm{N}$ should not be employed to facilitate earlier grazing or higher, early spring stocking rates because of the resulting greater mobilization of stored carbohydrates and lower yield returns. Results from the first 4 years of this study contributed to those conclusions, and the data obtained since strengthen them. In 1963 and 1969, significant reductions in

Table 4. Herbage crude protein concentration (\%) in 1963 and 1969 as influenced by clipping in 6 and 12 previous years.

\begin{tabular}{lcc}
\hline & Previous year's harvesting treatment \\
\cline { 2 - 3 } Time of harvest & May $15^{2}$ & Aug. 1 \\
\hline August 1,1963 & $8.2^{\mathrm{a}}$ & $7.6^{\mathrm{b}}$ \\
May 15,1969 & $16.4^{\mathrm{a}}$ & $16.5^{\mathrm{a}}$ \\
August 1,1969 (regrowth) & $10.8^{\mathrm{a}}$ & $11.1^{\mathrm{a}}$ \\
August 1, 1969 & $6.1^{\mathrm{a}}$ & $5.9^{\mathrm{a}}$ \\
\hline 1Means within a row with similar superscripts are not significantly different \\
(P< 0.05). \\
This treatment also includes the effects of harvesting the regrowth of these \\
grasses on August 1.
\end{tabular}


yield resulted from previous spring clipping treatment on fertilized plots. However, reductions in 1969 were less than in 1963, which suggests no accumulative effect; furthermore, there is no indication of diminishing yield through the years of this study. If the clipping influence is not accumulative, then the year immediately preceding the evaluation year must contain the answer for explaining these differences. In 1962 and 1968 limited opportunity existed for the replenishment of the depleted root carbohydrate reserve following harvesting on May 15. Regrowth in those two years was only 15 and $8 \%$ of their respective fall yields (Table 2). These regrowth values are below the $20 \%$ regrowth level indicated by Donart and Cook (1970) as that providing adequate restoration of carbohydrates. It is inferred that reductions in 1963 and 1969 due to previous clipping treatment in the presence of $\mathrm{N}$ are the result of low opportunity in the preceding year for restoration of root carbohydrate.

The impact of $\mathrm{N}$ fertilization combined with May 15 clipping upon the opportunity for root reserve restoration is further illustrated by the fact that in 5 years regrowth values were less than the $20 \%$ level, and in 2 other years approached that level. Regrowth from unfertilized grass exceeded the $20 \%$ level in all but 2 years. The inability of regrowth with $\mathrm{N}$ to achieve a sufficient level or production for root reserve restoration in those years despite production increases resulting from increased water use efficiency is probably related to the more rapid depletion of the soil water in the presence of N (Sneva et al., 1958) and consequently less total soil water remaining for growth after May 15.

These results confirm the conclusions presented earlier. It is conceivable that higher stocking rates could be employed during May to take advantage of the increased production with N. In so doing, the time of grazing termination becomes as important or possibly more important than the time of beginning grazing. It seems likely that with $\mathrm{N}$ the grazing period could become shorter. From a management viewpoint, this is undesirable.

Total production was $85 \%$ as much as that harvested on August 1 only. This amount is perhaps greater than could be expected from grazing, because grazing will occur over a longer period and returns will not be as great as that estimated by clipping. Slightly less than half the total two-crop yield was pro- duced as regrowth. The average regrowth amount of $286 \mathrm{lb}$./acre should provide adequate forage volume for grazing, but this is terminal production and no further growth additions should be expected. It is inferred from this that management of crested wheatgrass for providing late season forage is not well suited for this area of limited summer precipitation. However, late season forage is only one of several reasons for employing two-crop management of crested wheatgrass.

The significance of higher crude protein concentrations in the 1963 herbage from plots previously harvested in the spring is not clear. It is possible that this crude protein increase is a direct result of the associated yield decrease.

\section{Literature Cited}

Donart, Gary B., and C. Wayne Cook. 1970. Carbohydrate reserve content of mountain range plants following defoliation and regrowth. J. Range Manage. 23:15-19.

Eckert, Richard Edgar. 1957. Vegetation-soil relationships in some Artemisia types in northern Harney and Lake Counties, Oregon. Ph.D. Thesis. Ore. State Univ. 208 p.

Hyder, D. N., and F. A. Sneva. 1961. Fertilization on sagebrush-bunchgrass range. Ore. Agr. Exp. Sta. Misc. Paper \#115. 36 p.

Hyder, D. N. 1967. Pounds of forage per pound of beef. Proc. Ranch Manage. Conf. Tex. Tech. Coll. Lubbock, Texas. Oct. 13. 9 p.

Sharp, Lee A. 1970. Suggested management programs for grazing crested wheatgrass. Forest Wildlife and Range Exp. Sta. Univ. of Idaho. Bull. \#4. 19 p.

Sneva, Forrest A., D. N. Hyder, and C. S. Cooper. 1958. The influence of ammonium nitrate on the growth and yield of crested wheatgrass on the Oregon high desert. Agron. J. 50:40-44.

Sneva, Forrest A. 1965. Yield, yield-trend and response to nitrogen of introduced grasses on the Oregon high desert. Ore. Agr. Exp. Sta. Spec. Rpt. \#195. 18 p.

\title{
回區回
}

\section{Interaction of Fertility Level with Harvest Date and Frequency on Productiveness of Mixed Prairie}

\author{
RUSSELL J. LORENZ AND GEORGE A. ROGLER
}

Highlight: Management practices are needed which will insure sustained production from fertilized mixed prairie. Prior to establishing grazing management practices, a better understanding of $N$ and $P$ fertilizer effects on the vegetation is needed. The interaction of harvest date and frequency with annual applications of $N$ and $P$ was studied over an 8-year period near Mandan, N. Dak. Yield increases were significant when $40 \mathrm{lb}$. N/acre (40-N) and 80- $\mathrm{N}$ were applied, but application of 160-N produced little or no increase over the yield from 80-N. Average yields were 548, 1,298, 1,875 and 1,908 $\mathrm{lb} . /$ acre for the $0-, 40-, 80-$ and $160-N$ levels, respectively. Without $N$, response to $P$ was small and generally not significant. When $N$ was applied annually, response to $P$ became significant in the fourth and subsequent years. Yields at all fertilizer levels decreased as frequency of harvest increased. Greatest yield reductions occurred when the sequence included harvest in June.

The effects of $\mathrm{N}$ and $\mathrm{P}$ fertilizer on native grasslands have often been studied by measuring residual response over a period of years following a single application of fertilizer. Results from studies in the northern Great Plains of the United States and southwestern Canada have been varied. Less than $30 \mathrm{lb}$. elemental $\mathrm{N} /$ acre $(30-\mathrm{N})$ did not significantly increase dry matter production (Lodge,

The authors are research agronomists with the Plant Science Research Division, Agricultural Research Service, U. S. Department of Agriculture, U. S. Northern Great Plains Research Center, Mandan, North Dakota.

Contribution of the Plant Science Research Division, Agr. Res. Serv., U. S. Dep. Agr., Mandan, N. D.

Manuscript received December 31, 1971 .
1959) while higher rates occasionally did (Cosper and Thomas, 1961; Cosper et al., 1967; Smika et al., 1963; Kilcher et al., 1965; and Black, 1968) and rates greater than 60-N often did (Smoliak, 1965; Westin et al., 1955; and Mason and Miltimore, 1969). In many cases, the increase in production from single applications was not sufficient to be of economic value, but the fact that some increase in production did occur aroused interest in further study of fertilizer on mixed prairie.

Favorable results have been obtained from repeated annual applications of $\mathrm{N}$ to native grasslands. Westin et al. (1955) reported increased yields from application of 20-, 40- and 80-N when applied to 